\title{
The challenge of biological control of Cosmopolites sordidus Germar (Col. Curculionidae): A review
}

\author{
Paul Tresson ${ }^{1,2,3,4}$ (D) | Philippe Tixier ${ }^{1,2}$ (D) $\mid$ William Puech ${ }^{4}$ (D) | Dominique Carval ${ }^{1,2,3}$ (D)
}

${ }^{1}$ CIRAD, UPR GECO, Montpellier, France

${ }^{2} \mathrm{GECO}$, Univ Montpellier, CIRAD,

Montpellier, France

${ }^{3}$ CIRAD, UPR GECO, Saint-Pierre, France

${ }^{4}$ LIRMM, CNRS, Montpellier, France

Correspondence

Dominique Carval, GECO, Univ Montpellier, CIRAD, Montpellier, France.

Email: dominique.carval@cirad.fr

Funding information

European Community (ERDF); French National Research Agency under the Investments for the Future Program, Grant/ Award Number: ANR-16-CONV-0004

\begin{abstract}
The banana weevil (also known as banana root borer) Cosmopolites sordidus Germar (Coleoptera Curculionidae) is the major pest of banana and plantain. Because banana ranks 2 nd in fruit production worldwide, this pest has substantial social and economic importance. The biological control of the $C$. sordidus remains challenging because of its behaviour and resistance to parasitism and predation. The last review concerning the biological control of $C$. sordidus was published two decades ago, and relevant knowledge and methods have developed in the interim. The present paper provides an update of that knowledge and summarizes past and current challenges as well as providing perspectives on achieving sustainable control of $C$. sordidus. We first discuss studies on the classical biological control of $C$. sordidus, underlining the limits of classical biological control methods such as the importation of predators, parasitoids or pathogens. Next, we consider conservation biological control of $C$. sordidus, with a focus on ants. We also highlight an 'arthropod bias' that has led to a lack of information on the role of vertebrates in the regulation of $C$. sordidus.
\end{abstract}

\section{KEYWORDS}

ants, banana weevil, conservation biological control, Musa, predation, vertebrates

\section{1 | INTRODUCTION}

With growing human populations in Africa, Asia and South America, securing food production in tropical areas is increasingly important. Banana ranks 2nd in fruit production worldwide (FAO, 2018) and along with plantains is an essential component of the nutrition of a large population.

The most important pest of banana and plantain is the banana root borer Cosmopolites sordidus (Gold et al., 2001; Okolle et al., 2009). Females of this weevil lay eggs in the lower pseudostem and corm, and larvae develop in the corm. This weakens the plant and can lead to dramatic losses, both directly because of toppling and indirectly because of lower yields and increased infections by plant pathogens (Gold et al., 2001). Damage caused by C. sordidus is difficult to assess, however, because the immature stages of the weevil are hidden in the pseudostem and corm and their detection requires destructive sampling (Vilardebo, 1973). Furthermore, because the damage is not immediately visible and because $C$. sordidus effects are partly indirect, the full extent of $C$. sordidus damage is often underestimated until toppling occurs.

The banana weevil can be described as a K-selected species (Pianka, 1970), with a long holometabolan development (almost two months; Vinatier et al., 2009), a low fecundity (two eggs per week; Vinatier et al., 2009) and an extended lifespan (up to 4 years (Gold et al., 2001)). With these features, C. sordidus differs from pests like aphids, flies or moths that are typically $r$ selected species that generate damage because of their ability to rapidly produce large numbers of offspring (Williamson, 1996). However, K-selected species may also be important pests (Duyck et al., 2007).

Its $\mathrm{K}$-selected characteristics should have consequences for the biological control of $C$. sordidus. Because of its slow rate of 
reproduction, for example, the elimination of a few individuals could have a greater suppressive effect than the same level of suppression in the case of an r-selected pest. The cryptic behaviour of $C$. sordidus also alters the possible interactions with other species. The adults are active at night and are otherwise hidden in the soil (Carval et al., 2015) and larval stages take place inside the banana corm (Gold et al., 2001). These behavioural traits would have strong implications on the possibilities of biological control.

In most zones that produce banana for export, $C$. sordidus is controlled with insecticides (e.g. Armendariz et al., 2014; Okolle et al. 2020; Shinde et al., 2015). In the French West Indies (FWI), the use of chlordecone between 1972 and 1993 caused major and persistent public health problems (Devault et al., 2018; Joachim et al., 2019). For the past three decades, control of C. sordidus in FWI has relied on integrated pest management (IPM) strategies based on the use of pitfall traps emitting an aggregation pheromone, on fallow periods that break the reproductive cycle of the pest and on in vitro-produced banana plants (Beauhaire et al., 1995; Duyck et al., 2012; Okolle et al. 2020). However, these cultural practices have not yet been applied in many regions that produce export banana and are often unaffordable for small growers that produce banana and plantains for local markets. In the current context of biodiversity decline and the need for sustainable food production, biological control in general and conservation biological control $(\mathrm{CBC})$ in particular is needed for the banana weevil. Classical biological control can be achieved through the introduction of known enemies of a pest (DeBach \& Rosen, 1991) while CBC is based on the natural enemies hypothesis (see Elton, 1958; Root, 1973), that is, CBC relies on the conservation and augmentation of natural enemies already present in the geographic area of concern (Ehler, 1998). CBC is usually considered more sustainable than classical biological control, because imported species may attack non-target species (Stiling \& Cornelissen, 2005). Furthermore, the introduction of a single predator or parasite is not always followed by a decrease in pest numbers or damage (Letourneau et al., 2011).

Several studies have been conducted to identify enemies of $C$. sordidus. In 1951, Cuillé (1951) published a broad review of what was then known about $C$. sordidus and its control. A very complete review on IPM strategies was subsequently published by Gold et al. (2001). However, knowledge about the biological control of C. sordidus has increased since then and study methods are rapidly evolving. The aim of this article is to provide a synthesis of the recent knowledge and to highlight most promising perspectives on the biological control of $C$. sordidus, with a special emphasis on agroecological practices. First, we describe classical biological control via the importation of parasites, parasitoids or predators. We then review research on $C B C$, with emphasis on recent approaches including the use of environmental DNA metabarcoding and analysis of in-field images. Finally, we discuss how the constraints and biases that limit the biological control of $C$. sordidus can be overcome.

\section{BIOLOGICAL CONTROL OF Cosmopolites sordidus WITH INTRODUCED ORGANISMS}

\subsection{Limits of entomopathogenic fungi and nematodes}

Biological control of $C$. sordidus includes microbiological control with the entomopathogenic fungus Beauvaria bassiana, which has been shown to substantially reduce weevil populations in laboratory experiments (up to $100 \%$ larval mortality, Kaaya et al., 1993; Lopes et al., 2011), in greenhouse trials (up to $88.9 \%$ larval mortality, Akello et al., 2007) and with artificially inoculated weevils (42\% adult mortality, Godonou et al., 2000; 72\% mortality Nankinga \& Moore, 2000). Although results have been promising under these controlled settings, the efficiency of $B$. bassiana in the field is unclear (González et al., 2018; Lopes et al., 2014; Tinzaara et al., 2007). Tinzaara et al. (2007) explore the possibility of enhancing the dissemination of B. bassiana with the use of aggregation pheromones (sordidin, see Beauhaire et al., 1995). González et al. (2018) also assessed the suitability of the fungus Metarhizium anisopliae for microbiological control of $C$. sordidus and obtained results that were similar as B. bassiana (up to $76.9 \%$ of adult mortality under laboratory conditions and $48.5 \%$ in field trials). Consequently, fungus-based strategies remain scarcely used to control $C$. sordidus. Furthermore, B. bassiana has a broad host range (Devi et al., 2008; McKinnon et al., 2017) and may therefore be harmful to non-target species. The entomopathogenic nematodes Steinernema carpocapsae and Heterorhabditis bacteriophora have also been shown to control $C$. sordidus (up to 68\% infected larvae, Sepúlveda-Cano et al., 2008; Treverrow et al., 1991). To our knowledge, however, their effectiveness has only been documented under controlled conditions, and these nematodes can also parasitize a broad range of non-target species (de Doucet et al., 1999). Their potential effects on non-target organism have been discussed (e.g. Hodson et al., 2012).

\section{2 | Introduction of predators}

When looking for potential enemies of $C$. sordidus, researchers first searched the native region of $C$. sordidus. Since the beginning of the 20st century, researchers have looked for the pest's natural enemies in Java and Indonesia (Froggatt, 1924, 1928; Jepson, 1914). More recently, studies have identified Plaesius javanus (Coleoptera, Histeridae) and various ant species as potential predators of $C$. sordidus (Abera-Kalibata et al., 2006; Froggatt, 1928; Jepson, 1914).

For experimental purposes, some researchers introduced Indonesian predators of $C$. sordidus into new regions of banana production. In 1988, Neuenschwander et al. considered the feasibility of introducing several predators into Africa such as the beetles $P$. javanus, Hololepta quadridentata (Coleoptera, Histeridae), Plaesius laevigatus (Coleoptera, Histeridae) and Dactylosternum hydrophiloides (Coleoptera, Hydrophilidae), as well as the ant Tetramorium 
guineense (Hymenoptera, Myrmicinae) without further conclusions. Plaesius javanus has been successfully introduced and established to the Fiji and Jamaica, Hyposolenus laevigatus to Cook Island and Dominica, D. hydrophiloides to Australia and Jamaica and H. quadrientata (Coleoptera, Histeridae) to Saint Vincent. Following its introduction (Cruz \& Segarra, 1992), P. javanus has also been detected in Puerto Rico (Pantoja et al., 2007) but at low densities and with limited effects in terms of the biological control of $C$. sordidus; the authors found only three specimens of $P$. javanus in the harvest of 50 non-pesticide-treated plantain corms and the corms were heavily infested by $C$. sordidus. To our knowledge, there has not been further research on the introduction of predators to control $C$. sordidus since then.

\section{3 | Parasitism and parasitoids}

Parasitoids are used as control agents for various pests because they are often specific and effective (Brodeur \& Boivin, 2006). For these reasons, several parasitoids have been assessed for control of C. sordidus. In Benin, Traoré (1995) was unable to obtain control of $C$. sordidus with the parasitoid Anaphes victus (Hymenoptera: Mymaridae). In Uganda, researchers reported that no parasitoids emerged from $C$. sordidus eggs and larvae that were collected in the field and then incubated in the laboratory (Gold et al., 2001). The lack of effective parasitoids may be explained by the fact that the developmental stages of $C$. sordidus are mostly hidden and are therefore difficult for common species of parasitoid wasps or flies to access (Vinson, 1976).

Mites that were presumed to be parasitic were observed on $C$. sordidus adults (EIJaouhari, 2019). However, the mites have not been identified, and the thick cuticle of $C$. sordidus could prevent effective parasitism.

\section{3 | CONSERVATION BIOLOGICAL CONTROL OF Cosmopolites sordidus}

Given the lack of on-field success with classical biological control methods, researchers studying the biological control of $C$. sordidus in banana systems are now focusing on the control provided by generalist predators that naturally occur in banana fields. Agroecological banana systems currently designed are relying on introduction and the management of plant diversity, especially cover crop; more recently, there is a growing interest or on agroforestry (Poeydebat et al., 2017). In contrast to classical biological control, the aim of $C B C$ is to favour local species and to maximize the regulation they provide. $\mathrm{CBC}$ has the advantage of being sustainable over time, but its efficacy can be limited by the behaviour of $C$. sordidus. This is because adult banana weevils are relatively large, and therefore, predators must be either large or numerous to attack an adult or must be small enough to target the larval stages in the galleries in the corm.

\section{1 | Generalist arthropod predators}

Natural predators of $C$. sordidus were first studied in Javanese and Indonesian banana fields (Froggatt, 1924, 1928; Jepson, 1914) but have since been reported in every major banana production zone. In 1992 and 1993, Koppenhöfer and colleagues reported that the predators of various stages of $C$. sordidus were dominated by coleopterans and dermapterans including Eutochia pulla (Coleoptera, Tenebrionidae), Euborellia annulipes (Dermaptera, Anisolabididae) and Dactylosternum abdominale (Coleoptera, Hydrophilidae) (Koppenhöfer, 1993; Koppenhöfer et al., 1992). In the FWI, identified predators of $C$. sordidus include the ants Solenopsis geminata (Hymenoptera, Myrmicinae) and Camponotus sexguttatus (Hymenoptera, Formicinae), as well as earwig Euroborellia caraibea (Dermaptera, Anisolabididae) (Carval et al., 2016; Duyck et al., 2011; Mollot et al., 2012, 2014; Tixier et al., 2013). Poeydebat et al. (2017) found a negative correlation between generalist predator abundance and $C$. sordidus abundance. In Costa Rica, cockroaches have been observed to feed on exposed $C$. sordidus larvae (Tresson, Tixier, Puech, Bagny Beilhe, et al., 2019). Vinatier et al. (2009) also emphasized the effect of predators on the developmental stages of $C$. sordidus; the authors indicated that generalist predators and particularly egg predators help reduce banana weevil numbers.

\subsection{Special case of ants}

As early as the 1940s, Hargreaves (1940) suggested that ants are potential predators of the banana weevil. The subsequent advent of insecticides limited research on ants as predators of the pest. The predation of $C$. sordidus by ants has been proven, however, in various locations in Africa, South America and the Caribbeans (e.g. AberaKalibata et al., 2007; Armendariz et al., 2014 and Mollot et al., 2012, respectively). Ants may be more able than other predators to access the eggs and larvae of $C$. sordidus, which are located in the corm. As pointed out by Abera-Kalibata et al. (2007), ants have substantial foraging abilities and may therefore be useful predators of $C$. sordidus eggs and larvae. Ants are known to control other borer pests (Way et al., 1992; Way \& Khoo, 1992) and to be efficient generalist predators (Offenberg, 2015; Philpott \& Armbrecht, 2006). Although ants have been observed foraging in the tunnels of $C$. sordidus larvae (Abera-Kalibata et al., 2007), the tunnels were in a very damaged or within dead corms, and it is unclear whether ants could forage in galleries of more intact corms because such galleries are usually filled with latex (Gold et al., 2001). In a field study, Poeydebat et al. (2017) found that $C$. sordidus damage was negatively correlated with the abundance of omnivorous ants, but the abundance of $C$. sordidus adults was not correlated with the abundance of omnivorous ants; the authors therefore suggested that ants might preferentially attack eggs or immature stages of $C$. sordidus. The latter study and also Mollot et al. (2012) demonstrated the difficulty in quantifying the effects of ant-based $C B C$ on $C$. sordidus numbers. 
Since 1975 ability of ants to control C. sordidus has been studied extensively in Cuba, where Pheidole megacephala (Hymenoptera, Myrmicinae) and T. guineense have been identified as potential predators of C. sordidus (Bendicho, 1987; Castiñeiras \& Ponce, 1991; Neuenschwander et al., 1988; Roche, 1975; Roche \& Abreu, 1983). These species have therefore been deployed in Cuban banana plantations where they have been reported to control $C$. sordidus (Perfecto, 1994; Perfecto \& Castiñeiras, 1998).

The potential of predatory ants to regulate $C$. sordidus numbers has been investigated in Uganda by Abera-Kalibata et al. (2007), Abera-Kalibata et al. (2008); ants (Pheidole sp. and Odontomachus troglodytes (Hymenoptera, Ponerinae)) reduced numbers of $C$. sordidus eggs, larvae and pupae inside crop residues in controlled conditions (up to 65\% egg removal for Pheidole sp.). In a field trial, ant-enhanced plots showed 2.8 times less eggs per sucker than antexcluded plots ( $1.8 \pm 0.2$ versus $0.64 \pm 0.1$, respectively). However, at the end of a full growth cycle (30 months), damages were not significantly different. In Kenya and Cameroon as well, several ant species have been reported to be predators of $C$. sordidus (Dassou et al., 2015; Fansi \& Okolle, 2008; Uronu, 1992). In Cameroon, C. sordidus abundance was negatively correlated with the abundance of some ant species (Axinidris sp., Monomorium sp., Pheidole spp. and Tetramorium sp.). In the same study, the abundance of other species (Paratrechina longicornis (Hymenoptera, Formicinae), Camponotus spp. and $O$. troglodytes) was in contrast positively correlated with $C$. sordidus abundance, perhaps because the habitat was favourable for both the ants and the weevil or because of intra-guild predation and competition among on ant communities (Dassou et al., 2015). There is a promising field of research in unravelling what mosaics of habitats, composed of plants from different stata, plant residues, bare soil, favour most $C$. sordidus predatory ants.

Ants have also been hypothesized to be predators of $C$. sordidus in Venezuela (Goitia \& Cerda, 1998) and mentioned as predators of C. sordidus in Colombia and Ecuador (Armendariz et al., 2014). During several experiments in FWI, DNA metabarcoding and stable isotope analysis of gut contents demonstrated the role of ants (particularly S. geminata and C. sexguttatus) in the predation of $C$. sordidus (Duyck et al., 2011; Mollot et al., 2014; Tixier et al., 2013).

The value of ants as biological control agents may be ambiguous because they also can be regarded as pests in other crops or as harmful for the farmers (e.g. fire ants, see Eubanks, 2001). Moreover, for many ants that have been reported as potential predators of $C$. sordidus, identification was not always performed to the species level. Ant species of the same genus may behave very differently and may differ in size and diet, and this lack of species identification complicates the ability to assess the role of ants in C. sordidus control.

Photographs taken in the field allowed detailed analysis of the behaviours of different ant species in Costa Rica (Tresson, Tixier, Puech, Bagny Beilhe, et al., 2019). Camponotus atriceps (Hymenoptera, Formicinae) were observed to feed on dead adults but not on any living stages of $C$. sordidus; S. geminata consumed $C$. sordidus eggs and larvae but were unable to kill a live adult; Pheidole radoszkowskii (Hymenoptera, Myrmicinae), O. bauri and Nylanderia sp. consumed larvae and also were scavengers. Furthermore, a single individual of $O$. bauri was able to seize a larva, while at least five $P$. radoszkowskii were needed to capture a larva (Tresson, Tixier, Puech, Bagny Beilhe, et al., 2019). Ants show a great variety of behaviour, size and activities that are relevant to their role as biological control agents.

\section{3 | Vertebrates as predators}

Reports of predation of $C$. sordidus by vertebrates have generally been considered to be anecdotal (Gold et al., 2001). The giant toad Rhinella marina (Dawl, 1985) and the large arboreal lizard Anolis cristaelus (Wolcott, 1923) have been reported as predators of the C. sordidus. In New South Wales, Australia, Hely et al. (1982) suggested that rats, bandicoots frogs and birds may as well be predators of $C$. sordidus. Radiotelemetry approaches (Vinatier et al., 2010) may provide new information on predation by the toad Rhinella marina (F. Vinatier, 2019, pers. com.). Overall, biological control studies often focus on the predation of arthropods by other arthropods and often ignore predation by other taxa. This arthropod bias could result in an underestimation of the predation of $C$. sordidus by other taxa (see Section 4.2).

\section{4 | Diversification of plant species may favour CBC}

Diversification of plant species in the field is now often suggested as a way to increase regulation of $C$. sordidus by natural enemies (Mollot et al., 2012; Poeydebat et al., 2017; Tixier et al., 2013). The abundance of predators was generally higher in more diversified systems (Dassou et al., 2016); in this study, associated plants to plantain included in particular cocoa trees (Theobroma cacao), palm trees (Elaeis guineensis), papaya and a wide range of root and tuber vegetables. The addition of a new plant species (in particular grasses from the family of Poaceae as Brachiara decumbes and Cynodon dactylon) in a banana field can reduce the intra-guild predation and thereby favour predation of $C$. sordidus (Duyck et al., 2011; Tixier et al., 2013). Predation of $C$. sordidus eggs was higher in plots with cover crops (B. decumbes) than with bare soil (Mollot et al., 2012). Very simple diversification strategies, however, can result in less predation of $C$. sordidus than occurs with bare soil. Mollot et al. (2014), for instance, showed that predators consumed fewer $C$. sordidus in a monospecific cover crop of B. decumbens than on bare soil. Similarly, Carval et al. (2016) found that a monospecific cover of Paspalum notatum reduced $C$. sordidus abundance but not $C$. sordidus damage to banana plants. These latter two studies suggest that more complex plant diversification may be needed to enhance the natural control provided by predators. The integration of shrubs and trees appears to be useful for enhancing predation in general and predation by ants in particular (Dassou et al., 2017). Diversification may also have a dilution effect on pests, diminishing their abundance (Root, 1973). Finally, 


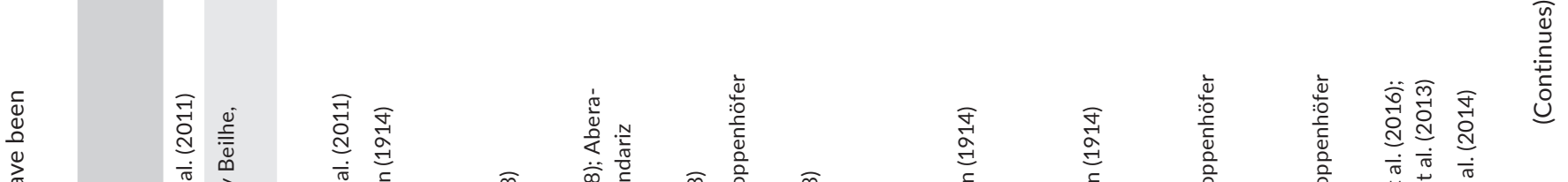

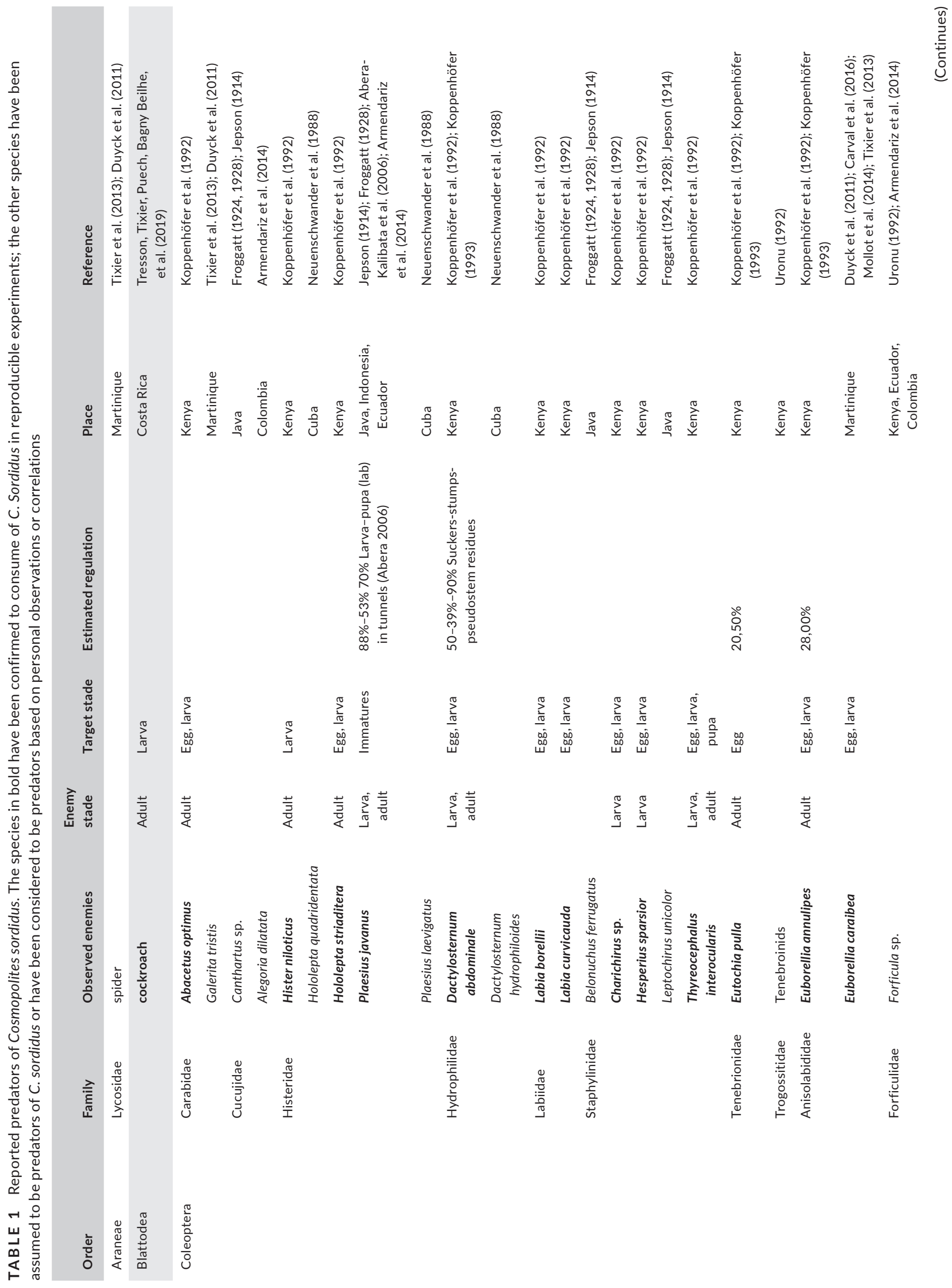




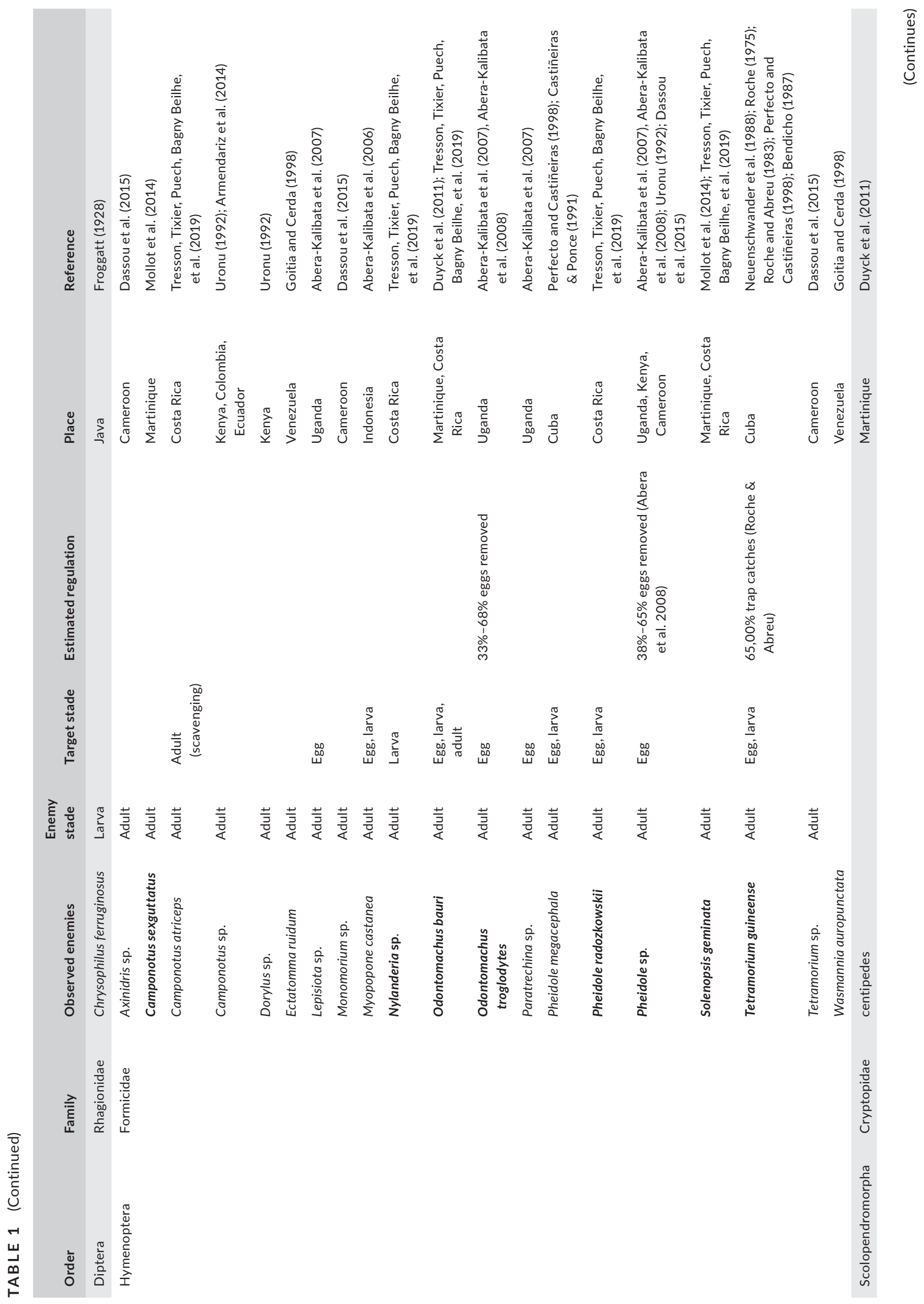




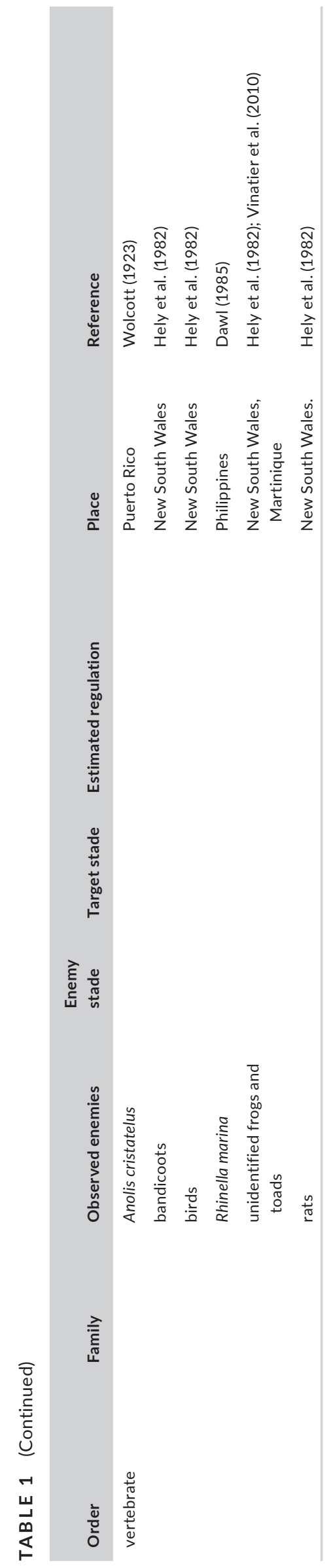

Collard et al. (2018), who used a modelling approach, recommended that $\mathrm{CBC}$ could be enhanced by increasing the edge length or interface between the crop and non-crop habitat of the predators.

\subsection{Limits of CBC}

$\mathrm{CBC}$ is by nature very context-dependent. This can be a major drawback when studying or applying CBC (Rusch et al., 2017). Ecological communities and their predation services may be specific to certain regions or landscapes. It can therefore be a heavy constraint for a farmer to conduct a diverse agrosystem without guaranty of success if a desired predator species does provide regulation services.

\section{4 | DISCUSSION}

\subsection{Accurate assessment of $C$. sordidus abundance, damage to the crop and regulation by predators}

Accurate assessment of $C$. sordidus populations is still difficult, because pitfall traps catch only adults, and enumerating eggs and larvae is destructive. Furthermore, damage is not always well correlated with numbers of adults (Gold et al., 2001; Poeydebat et al., 2017). Quantifying with certitude the effect of a given species of predator on $C$. sordidus abundance and damage is also difficult. Although these assessments are possible under controlled conditions, the assessments obtained may not be transferable to the field. For instance, the efficient regulation of $C$. sordidus by ants under controlled conditions in the greenhouse (Abera-Kalibata et al., 2008) has not been reported in field trials. Accurate damage assessment is also difficult because it is destructive and can therefore be estimated only after harvest. $C$. sordidus damage is usually measured by using the coefficient of infestation proposed by Vilardebo (1973) or by using methods based on the coefficient of infestation (e.g. Ogenga-Latigo \& Bakyalire, 1993). This coefficient relies on a subjective scoring by the researcher while observing a corm cross section ( 0 being a sane corm and 100 a fully infested corm). The difficulties in assessing $C$. sordidus numbers and damage have limited the ability of researchers to produce quantitative and accurate results (Ogenga-Latigo \& Bakyalire, 1993). New approaches are therefore needed to achieve a non-destructive and accurate measurement of $C$. sordidus populations and damages. An interesting perspective would be to improve the damage indicator used on banana and to standardize the measurement of the predation intensity, for instance using sentinel cards.

As noted above, assessment of predation is also difficult and can be considered imprecise for most of the studies presented in this review. In Table 1, species that have been identified with certainty as predators of $C$. sordidus are highlighted. When available, assessments or estimates of $C$. sordidus population regulation are also provided. Most of the studies conducted before 2000 identified 
organisms as predators of $C$. sordidus based only on limited observation or on common knowledge; that is, the status of the organism as a predator was not firmly established.

Densities and a closed space, for example, could alter the feeding behaviour of a predator. The cryptic and nocturnal behaviour of $C$. sordidus tends to suggest that potential predators should be either nocturnal or with abilities to search in the soil and in plant residues. Within controlled conditions, some predators may have consumed weevils but since they have diurnal feeding behaviour in natural settings, they are unlikely to be effective predators in field conditions.

More recent studies have mostly relied on correlation to infer the regulation of $C$. sordidus by predators. Although these assessments are usually conducted in the field and therefore reflect the reality of the field, correlative approaches cannot prove cause-and-effect, that is, cannot demonstrate with certainty the predation of $C$. sordidus by a given species of predator.

Most recently, the DNA contained in gut content appears to have a great potential to prove the trophic link between a predator and its preys in field conditions (Sow et al., 2020), but to date such approaches still need to be applied in broader conditions to provide a wider insight on $C$. sordidus predation. This method has been applied to the identification of species as predators of $C$. sordidus were done (Mollot et al., 2014). As mentioned by the latter authors, however, there are also biases with the use of metabarcoding, in particular with ant predation. Because of the social behaviour of ants, the stomach content of a worker may not reflect the collective regime of a colony. For instance, even though Mollot et al. (2014) observed S. geminata workers capturing C. sordidus eggs, the authors failed to find residues of $C$. sordidus DNA in the stomachs of workers. Mollot et al. (2014) proposed that the eggs might have been fed to and consumed by the larvae rather than by the foraging workers. Metabarcoding also does not enable researchers to discriminate between predation, scavenging and secondary predation (Hagler, 2019).

More recently, methods have been developed that rely on the combined use of sentinel prey and automated image analysis (Tresson, Tixier, Puech, Bagny Beilhe, et al., 2019; Tresson, Tixier, Puech, \& Carval, 2019). Images as a source of information have the advantage of showing predation with certainty and with fewer behavioural biases than occur in laboratory experiments. Automated image analysis enables the recording of real predation events under relatively unbiased field conditions (see Grieshop et al., 2012; Zou et al., 2017). Furthermore, the combined use of sentinel prey cards and automated image analysis enables researchers to differentiate between trophic and non-trophic interactions in the arthropod community.

\section{2 | Arthropod bias}

As noted earlier in this review, most studies of predation of $C$. sordidus have focused on predation by arthropods (mainly insects). Among the 49 studies reviewed in this paper, only three mentioned vertebrates as predators (Dawl, 1985; Hely et al., 1982; Wolcott, 1923). This may be due to the methods used to assess biodiversity (e.g. pitfall traps), which readily sample small animals (and therefore arthropods) rather than vertebrates. For instance, Zou et al. (2017) used video monitoring to determine that predation of brown planthopper by frogs in rice fields was substantially underestimated. Given that the banana weevil is a relatively large insect, it is reasonable to suspect that predation by larger animals (toads, lizards, rats etc.) may be significant. Therefore, further studies should be conducted to assess the potential of regulation of C. sordidus by vertebrates. This could be achieved by experiments combining the use of sentinel prey and automated image analysis in experimental or production plots. It would also be valuable to better quantify the importance of predation of $C$. sordidus by vertebrates (toads, lizards, birds, etc.) using exclusion experiments in field conditions.

\section{5 | CONCLUSION}

The biological control of $C$. sordidus is an old but persistent challenge in all banana production zones. After a century of research across the globe, we are able to draw several conclusions about the biological control of $C$. sordidus. Classical biological control of this pest seems to be ineffective. Recent studies therefore tend to favour $\mathrm{CBC}$ and generalist predators. Among generalist predators, ants seem capable of attacking eggs and larvae of $C$. sordidus. However, our understanding of the trophic network around $C$. sordidus and of predator reduction of the damage caused by $C$. sordidus requires improvement. Most of the knowledge about the predation of $C$. sordidus comes either from laboratory experiments or from observations and correlations, that is, with so much control of organisms and conditions such that we do not gain much understanding of actual behaviour in the field or with so little control of organisms and conditions that causal relationships remain uncertain. As a consequence, our understanding of the regulation of $C$. sordidus by predators remains quite limited. However, novel approaches such as the use of images, immunomarking techniques or metabarcoding may help better understand the behaviour of $C$. sordidus and its enemies on the field.

\section{ACKNOWLEDGEMENTS}

This review was carried out as part of the CIRAD DPP COSAQ agronomical research programme (activities 20152021) funded by a grant from the European Community (ERDF) and the Conseil Régional de La Réunion. This review was also supported by the French National Research Agency under the Investments for the Future Program, ANR-16-CONV-0004. The Ph.D. thesis of P. Tresson was funded by CIRAD and \#DigitAg grants. The authors thank Bruce Jaffee for revision of the English composition of the manuscript.

\section{CONFLICTS OF INTEREST}

All the co-authors declare that they have no conflict of interest. 


\section{AUTHOR CONTRIBUTION}

P.T., D.C. and Ph.T conceived research. P.T. reviewed the literature. P.T., D.C. and Ph.T. wrote the manuscript. All authors read and approved the manuscript.

\section{ORCID}

Paul Tresson (iD https://orcid.org/0000-0002-1275-4673

Philippe Tixier (D) https://orcid.org/0000-0001-5147-9777

William Puech (iD https://orcid.org/0000-0001-9383-2401

Dominique Carval iD https://orcid.org/0000-0002-1525-2855

\section{REFERENCES}

Abera-Kalibata, A. M., Gold, C. S., \& Van Driesche, R. (2008). Experimental evaluation of the impacts of two ant species on banana weevil in Uganda. Biological Control, 46, 147-157. https://doi.org/10.1016/j. biocontrol.2008.04.017

Abera-Kalibata, A. M., Gold, C. S., Van Driesche, R. G., \& Ragama, P. E. (2007). Composition, distribution, and relative abundance of ants in banana farming systems in Uganda. Biological Control, 40, 168-178. https://doi.org/10.1016/j.biocontrol.2006.11.006

Abera-Kalibata, A. M., Hasyim, A., Gold, C. S., \& Van Driesche, R. (2006). Field surveys in Indonesia for natural enemies of the banana weevil, Cosmopolites sordidus (Germar). Biological Control, 37, 16-24. https:// doi.org/10.1016/j.biocontrol.2005.11.009

Akello, J., Dubois, T., Gold, C. S., Coyne, D., Nakavuma, J., \& Paparu, P. (2007). Beauveria bassiana (Balsamo) Vuillemin as an endophyte in tissue culture banana (Musa spp.). Journal of Invertebrate Pathology, 96, 34-42. https://doi.org/10.1016/j.jip.2007.02.004

Armendariz, I., Landzuri, P., \& Ulloa, S. (2014). Buenas practicas para el control del Picudo del Platano, Cosmpolites sordidus, en Ecuador. Technical Report Universidad de las Fuerzas Armadas, ESPE. IASA 1 y 2.

Beauhaire, J., Ducrot, P.-H., Malosse, C., Rochat, D., Ndiege, I. O., \& Otieno, D. O. (1995). Identification and synthesis of sordidin, a male pheromone emitted by Cosmopolites sordidus. Tetrahedron Letters, 36, 1043-1046. https://doi.org/10.1016/0040-4039(94)02437-G

Bendicho, A. (1987). Poder de percepcíon de la hormiga Tetramorium guineense para el control biologico del picudo negro del platano. Technical Report Instituto de Investigaciones de Sanidad Vegetal.

Brodeur, J., \& Boivin, G. (2006). Trophic and guild interactions in biological control. Springer.

Carval, D., Perrin, B., Duyck, P.-F., \& Tixier, P. (2015). Local and neighboring patch conditions alter sex-specific movement in banana weevils. Ecology and Evolution, 5, 5735-5743. https://doi.org/10.1002/ ece3.1818

Carval, D., Resmond, R., Achard, R., \& Tixier, P. (2016). Cover cropping reduces the abundance of the banana weevil Cosmopolites sordidus but does not reduce its damage to the banana plants. Biological Control, 99, 14-18. https://doi.org/10.1016/j.biocontrol.2016.04.004

Castiñeiras, A., \& Ponce, E. (1991). Efectividad de la utilizacíon de Pheidole megacephala (Hymenoptera: Formicidae) en la lucha biológica contra Cosmopolites sordidus (Coleoptera: Curculionidae). Technical Report Instituto de Investigaciones de Sanidad Vegetal.

Collard, B., Tixier, P., Carval, D., Lavigne, C., \& Delattre, T. (2018). Spatial organisation of habitats in agricultural plots affects per-capita predator effect on conservation biological control: An individual based modelling study. Ecological Modelling, 388, 124-135. https://doi. org/10.1016/j.ecolmodel.2018.09.026

Cruz, C., \& Segarra, A. (1992). Potential for biological control of crop pests in the Caribbean. Florida Entomologist, 75, 400-400. https:// doi.org/10.2307/3496120

Cuillé, J. (1951). Récentes améliorations des procédés de lutte utilisables contre le charançon du bananier. Fruits, 6, 280-284.
Dassou, A. G., Carval, D., Dépigny, S., Fansi, G., \& Tixier, P. (2015). Ant abundance and Cosmopolites sordidus damage in plantain fields as affected by intercropping. Biological Control, 81, 51-57. https://doi. org/10.1016/j.biocontrol.2014.11.008

Dassou, A. G., Dépigny, S., Canard, E., Vinatier, F., Carval, D., \& Tixier, P. (2016). Contrasting effects of plant diversity across arthropod trophic groups in plantain-based agroecosystems. Basic and Applied Ecology, 17, 11-20. https://doi.org/10.1016/j.baae.2015.09.003

Dassou, A. G., Tixier, P., Dépigny, S., \& Carval, D. (2017). Vegetation structure of plantain-based agrosystems determines numerical dominance in community of ground-dwelling ants. PeerJ, 5, e3917. https://doi.org/10.7717/peerj.3917

Dawl, N. (1985). Insect pest management in banana. Proc. Inter. SeminarWorkshop Banana Plantain Res. Dev. (pp. 100-5).

de Doucet, M., Bertolotti, M., Giayetto, A., \& Miranda, M. (1999). Host range, specificity, and virulence of Steinernema feltiae, Steinernema rarum, and Heterorhabditis bacteriophora (Steinernematidae and Heterorhabditidae) from Argentina. Journal of Invertebrate Pathology, 73, 237-242. https://doi.org/10.1006/jipa.1998.4831

DeBach, P., \& Rosen, D. (1991). Biological control by natural enemies. CUP Archive.

Devault, D. A., Karolak, S., Levi, Y., Rousis, N. I., Zuccato, E., \& Castiglioni, S. (2018). Exposure of an urban population to pesticides assessed by wastewater-based epidemiology in a Caribbean island. Science of the Total Environment, 644, 129-136. https://doi.org/10.1016/j.scito tenv.2018.06.250

Devi, K. U., Padmavathi, J., Rao, C. U. M., Khan, A. A. P., \& Mohan, M. C. (2008). A study of host specificity in the entomopathogenic fungus Beauveria bassiana (Hypocreales, Clavicipitaceae). Biocontrol Science and Technology, 18, 975-989. https://doi.org/10.1080/0958315080 2450451

Duyck, P.-F., David, P., \& Quilici, S. (2007). Can more k-selected species be better invaders? A case study of fruit flies in la Réunion. Diversity and Distributions, 13, 535-543. https://doi. org/10.1111/j.1472-4642.2007.00360.x

Duyck, P. F., Dortel, E., Vinatier, F., Gaujoux, E., Carval, D., \& Tixier, P. (2012). Effect of environment and fallow period on Cosmopolites sordidus population dynamics at the landscape scale. Bulletin of Entomological Research, 102, 583-588. https://doi.org/10.1017/ S0007485312000089

Duyck, P.-F., Lavigne, A., Vinatier, F., Achard, R., Okolle, J. N., \& Tixier, P. (2011). Addition of a new resource in agroecosystems: Do cover crops alter the trophic positions of generalist predators? Basic and Applied Ecology, 12, 47-55. https://doi.org/10.1016/j.baae.2010.11.009

Ehler, L. (1998). Chapter 1 - Conservation biological control: Past, present, and future. In P. Barbosa (Ed.), Conservation biological control (pp. 1-8). Academic Press. https://doi.org/10.1016/B978-0120781478/50047-5

ElJaouhari, M. (2019). La lutte biologique par conservation du charançon noir (Cosmopolites sordidus) par les prédateurs du sol en fonction des pratiques agricoles des bananeraies de la Martinique. Master's thesis, Montpellier SupAgro Montpellier, France.

Elton, C. S. (1958). The ecology of invasions by plants and animals. Methuen.

Eubanks, M. (2001). Estimates of the direct and indirect effects of red imported fire ants on biological control in field crops. Biological Control, 21, 35-43. https://doi.org/10.1006/bcon.2001.0923

Fansi, G., \& Okolle, J. N. (2008). Dix années de travaux sur le charançon noir du bananier Expérience d'un technicien. Technical Report Laboratoire de nématologie/entomologie, CARBAP.

FAO. (2018). Faostat. Retrieved from http://www.fao.org/faostat/ en/\#data/QC

Froggatt, J. (1924). Banana weevil borer (Cosmopolites sordidus). Queensland Agricultural Journal, 21, 369-378.

Froggatt, J. (1928). Banana weevil borer in Java with notes on other crop pests. Queensland Agricultural Journal, 6, 530-541. 
Godonou, I., Green, K. R., Oduro, K. A., Lomer, C. J., \& Afreh-Nuamah, K. (2000). Field evaluation of selected formulations of Beauveria bassiana for the management of the banana weevil (Cosmopolites sordidus) on plantain (Musa spp., AAB group). Biocontrol Science and Technology, 10, 779-788. https://doi.org/10.1080/09583150020011726

Goitia, W., \& Cerda, H. (1998). Hormigas y otros insectos asociados a musáceas y su relacíon con Cosmopolites sordidus Germar (Coleoptera: Curculinoide);[ants and other insects associated to bananas and their relationship with Cosmopolites sordidus Germar (Coleoptera: Curculinoide)]. Agronomía Tropical (Venezuela), 48, 209-224.

Gold, C. S., Pena, J. E., \& Karamura, E. B. (2001). Biology and integrated pest management for the banana weevil Cosmopolites sordidus (Germar) (Coleoptera: Curculionidae). Integrated Pest Management Reviews, 6, 79-155. https://doi.org/10.1023/A:1023330900707

González, D. N., Chávez, M. A. A., Gutíerrez, R. L., Cupul, W. C., Ochoa, J. M., \& Velasco, E. G. (2018). Suitability of Cordyceps bassiana and Metarhizium anisopliae for biological control of Cosmopolites sordidus (Germar) (Coleoptera: Curculionidae) in an organic Mexican banana plantation: Laboratory and field trials. Journal of Plant Diseases and Protection, 125, 73-81. https://doi.org/10.1007/s41348-017-0126-4

Grieshop, M. J., Werling, B., Buehrer, K., Perrone, J., Isaacs, R., \& Doug, L. (2012). Big brother is watching: Studying insect predation in the age of digital surveillance. American Entomologist, 58, 11. https://doi. org/10.1093/ae/58.3.172

Hagler, J. R. (2019). Its gut check time! A universal food immunomarking technique for studying arthropod feeding activities. Annals of the Entomological Society of America, 112, 211-219. https://doi. org/10.1093/aesa/say040

Hargreaves, H. (1940). Insect pests of bananas. In J. D. Tothill (Ed.), Agriculture in Uganda (p. 121). Oxford University Press.

Hely, P. C., Pasfield, G., \& Gellatley, J. G. (1982). Insect pests of fruit and vegetables in NSW. Department of Agriculture.

Hodson, A., Siegel, J., \& Lewis, E. (2012). Ecological influence of the entomopathogenic nematode, Steinernema carpocapsae, on pistachio orchard soil arthropods. Pedobiologia, 55, https://doi.org/10.1016/j. pedobi.2011.10.005

Jepson, F. (1914). A mission to Java in quest of natural enemies for a Coleopterous pest of bananas (Cosmopolites sordidus).

Joachim, C., Veronique-Baudin, J., Ulric-Gervaise, S., Pomier, A., Pierre-Louis, A., Vestris, M., Novella, J.-L., Drame, M., Macni, J., \& Escarmant, P. (2019). Cancer burden in the Caribbean: An overview of the Martinique cancer registry profile. BMC Cancer, 19, 239. https://doi.org/10.1186/s12885-019-5434-6

Kaaya, G. P., SeshuReddy, K. V., Kokwaro, E. D., \& Munyinyi, D. M. (1993). Pathogenicity of Beauveria bassiana, Metarhizium anisopliae and Serratia marcescens to the banana weevil Cosmopolites sordidus. Biocontrol Science and Technology, 3, 177-187. https://doi. org/10.1080/09583159309355274

Koppenhöfer, A. (1993). Egg predators of the banana weevil, Cosmopolites sordidus (Germar) (Col., Curculionidae) in western Kenya. Journal of Applied Entomology, 116, 352-357.

Koppenhöfer, A., Reddy, K. S., Madel, G., \& Lubega, M. (1992). Predators of the banana weevil, Cosmopolites sordidus (Germar) (Col., Curculionidae) in western Kenya. Journal of Applied Entomology, 114, 530-533.

Letourneau, D. K., Armbrecht, I., Rivera, B. S., Lerma, J. M., Carmona, E. J., Daza, M. C., Escobar, S., Galindo, V., Gutirrez, C., Lpez, S. D., Meja, J. L., Rangel, A. M. A., Rangel, J. H., Rivera, L., Saavedra, C. A., Torres, A. M., \& Trujillo, A. R. (2011). Does plant diversity benefit agroecosystems? A synthetic review. Ecological Applications, 21, 921. https://doi.org/10.1890/09-2026.1

Lopes, R. B., Laumann, R. A., Moore, D., Oliveira, M. W. M., \& Faria, M. (2014). Combination of the fungus Beauveria bassiana and pheromone in an attract-and-kill strategy against the banana weevil, Cosmopolites sordidus. Entomologia Experimentalis Et Applicata, 151, 75-85.
Lopes, R. B., Michereff-Filho, M., Tigano, M. S., Neves, P., Lopez, E. L., Fancelli, M., da Silva, J. P. (2011). Virulence and horizontal transmission of selected Brazilian strains of Beauveria bassiana against Cosmopolites sordidus under laboratory conditions. Bulletin of Insectology, 64, 201-208.

McKinnon, A. C., Saari, S., Moran-Diez, M. E., Meyling, N. V., Raad, M., \& Glare, T. R. (2017). Beauveria bassiana as an endophyte: A critical review on associated methodology and biocontrol potential. BioControl, 62, 1-17. https://doi.org/10.1007/s10526-016-9769-5

Mollot, G., Duyck, P.-F., Lefeuvre, P., Lescourret, F., Martin, J.-F., Piry, S., Canard, E., \& Tixier, P. (2014). Cover cropping alters the diet of arthropods in a banana plantation: A metabarcoding approach. PLoS One, 9, 1-9. https://doi.org/10.1371/journal.pone.0093740

Mollot, G., Tixier, P., Lescourret, F., Quilici, S., \& Duyck, P.-F. (2012). New primary resource increases predation on a pest in a banana agroecosystem. Agricultural and Forest Entomology, 14, 317-323. https://doi. org/10.1111/j.1461-9563.2012.00571.x

Nankinga, C., \& Moore, D. (2000). Reduction of banana weevil populations using different formulations of the entomopathogenic fungus Beauveria bassiana. Biocontrol Science and Technology, 10, 645-657. https://doi.org/10.1080/095831500750016442

Neuenschwander, P. (1988). Prospects and proposals for biological control of Cosmopolites sordidus (germar)(coleoptera curculionidae) in Africa. Nematodes and the borer weevil in bananas. Present status of research and outlook (pp. 54-57).

Offenberg, J. (2015). Review: Ants as tools in sustainable agriculture. Journal of Applied Ecology, 52, 1197-1205. https://doi. org/10.1111/1365-2664.12496

Ogenga-Latigo, M., \& Bakyalire, R. (1993). Use of pseudostem traps and coefficient of infestation ( $p c i)$ for assessing banana infestation and damage by Cosmopolites sordidus Germar. African Crop Science Journal, 1.

Okolle, J. N., Fansi, G. H., Lombi, F. M., Sama Lang, P., \& Loubana, P. M. (2009). Banana entomological research in Cameroon: How far and what next. The African Journal of Plant Science and Biotechnology, 3, 1-19.

Okolle, N. J., Ngosong, C., Nanganoa, L. T., \& Dopgima, L. L. (2020). Alternatives to synthetic pesticides for the management of the banana borer weevil (Cosmopolites sordidus) (Coleoptera: Curculioniidae). CAB Reviews, 15(026), 1-24. https://doi.org/10.1079/PAVSNNR202 015026

Pantoja, A., Franqui, R. A., \& Salazar, A. (2007). Recovery of Plaesius javanus Erichson from plantains in Puerto Rico. Journal of Agriculture of the University of Puerto Rico, 91, 215-217.

Perfecto, I. (1994). The transformation of Cuban agriculture after the cold war. American Journal of Alternative Agriculture, 9, 98-108. https://doi.org/10.1017/S0889189300005762

Perfecto, I., \& Castiñeiras, A. (1998). Deployment of the predaceous ants and their conservation in agroecosystems. In Conservation biological control (pp. 269-289). Elsevier.

Philpott, S. M., \& Armbrecht, I. (2006). Biodiversity in tropical agroforests and the ecological role of ants and ant diversity in predatory function. Ecological Entomology, 31, 369-377. https://doi. org/10.1111/j.1365-2311.2006.00793.x

Pianka, E. R. (1970). On r- and k-selection. The American Naturalist, 104, 592-597. https://doi.org/10.1086/282697

Poeydebat, C., Tixier, P., Bellaire, L. D. L. D., \& Carval, D. (2017). Plant richness enhances banana weevil regulation in a tropical agroecosystem by affecting a multitrophic food web. Biological Control, 114, 125-132. https://doi.org/10.1016/j.biocontrol.2017.08.009

Roche, R. (1975). Comunicación preliminar sobre la hormiga tetramorium guineense, control biológico del Picudo Negro del Plátano. Revista De Agricultura, 8, 35-37.

Roche, R., Abreu, S. (1983). Control del picudo negro del plátano (Cosmopolites sordidus) por la hormiga Tetramorium guineense. Technical Report Instituto de Investigaciones de Sanidad Vegetal. 
Root, R. B. (1973). Organization of a plant-arthropod association in simple and diverse habitats: The fauna of collards (Brassica oleracea). Ecological Monographs, 43, 95-124. https://doi.org/10.2307/1942161

Rusch, A., Bommarco, R., \& Ekbom, B. (2017). Conservation biological control in agricultural landscapes. In Advances in botanical research (Vol. 81, pp. 333-360). Elsevier.

Sepúlveda-Cano, P. A., López-Núñez, J. C., \& Soto-Giraldo, A. (2008). Effect of two enthomopathogenic nematodes on Cosmopolites sordidus (coleoptera: Dryophthoridae). Revista Colombiana De Entomología, 34, 62-67.

Shinde, D., Wadaskar, P., \& Bhoyar, M. (2015). Banana weevil and its management. Indian Farmer, 2, 182-184.

Sow, A., Haran, J., Benoit, L., Galan, M., \& Brévault, T. (2020). DNA metabarcoding as a tool for disentangling food webs in agroecosystems. Insects, 11, 294. https://doi.org/10.3390/insects11050294

Stiling, P., \& Cornelissen, T. (2005). What makes a successful biocontrol agent? A meta-analysis of biological control agent performance. Biological Control, 34, 236-246. https://doi.org/10.1016/j.bioco ntrol.2005.02.017

Tinzaara, W., Gold, C. S., Dicke, M., Huis, A. V., Nankinga, C. M., Kagezi, G. H., \& Ragama, P. E. (2007). The use of aggregation pheromone to enhance dissemination of Beauveria bassiana for the control of the banana weevil in Uganda. Biocontrol Science and Technology, 17, 111124. https://doi.org/10.1080/09583150600937089

Tixier, P., Dagneaux, D., Mollot, G., Vinatier, F., \& Duyck, P.-F. (2013). Weeds mediate the level of intraguild predation in arthropod food webs. Journal of Applied Entomology, 137, 702-710. https://doi. org/10.1111/jen.12060

Traoré, L. (1995). Facteurs biologiques de mortalité de Curculionidae en milieux tempéré et tropical. PhD thesis, McGill University, Montreal, Canada, $192 \mathrm{pp}$.

Tresson, P., Tixier, P., Puech, W., Bagny Beilhe, L., Roudine, S., Pagès, C., \& Carval, D. (2019). Corigan: Assessing multiple species and interactions within images. Methods in Ecology and Evolution, 10, 1888-1893. https://doi.org/10.1111/2041-210X.13281

Tresson, P., Tixier, P., Puech, W., \& Carval, D. (2019). Insect interaction analysis based on object detection and CNN. In IEEE MMSP 2019. Kuala Lumpur, Malaysia. Retrieved from https://hal.archives-ouver tes.fr/hal-02361210

Treverrow, N., Bedding, R. A., Dettmann, E. B., \& Maddox, C. (1991). Evaluation of entomopathogenic nematodes for control of Cosmopolites sordidus Germar (Coleoptera: Curcilionidae), a pest of bananas in Australia. Annals of Applied Biology, 119, 139-145. https:// doi.org/10.1111/j.1744-7348.1991.tb04852.x
Uronu, B. (1992). The effect of plant resistance and cultural practices on the population densities of banana weevil Cosmopolites sordidus (Germar) and on banana yield. PhD thesis, Kenyatta University, Nairobi, Kenya, 216 pp.

Vilardebo, A. (1973). The coefficient of infestation, criterion of evaluation of the degree of attack of banana plants by Cosmopolites sordidus Germ., the black banana weevil.

Vinatier, F., Chailleux, A., Duyck, P.-F., Salmon, F., Lescourret, F., \& Tixier, P. (2010). Radiotelemetry unravels movements of a walking insect species in heterogeneous environments. Animal Behaviour, 80, 221-229.

Vinatier, F., Tixier, P., Page, C. L., Duyck, P.-F., \& Lescourret, F. (2009). Cosmos, a spatially explicit model to simulate the epidemiology of Cosmopolites sordidus in banana fields. Ecological Modelling, 220, 2244-2254. https://doi.org/10.1016/j.ecolmodel.2009.06.023

Vinson, S. B. (1976). Host selection by insect parasitoids. Annual Review of Entomology, 21, 109-133. https://doi.org/10.1146/annur ev.en.21.010176.000545

Way, M., Cammell, M., \& Paiva, M. (1992). Studies on egg predation by ants (Hymenoptera: Formicidae) especially on the eucalyptus borer Phoracantha semipunctata (Coleoptera: Cerambycidae) in Portugal. Bulletin of Entomological Research, 82, 425-432. https://doi. org/10.1017/S0007485300041225

Way, M. J., \& Khoo, K. C. (1992). Role of ants in pest management. Annual Review of Entomology, 37, 479-503. https://doi.org/10.1146/annur ev.en.37.010192.002403

Williamson, M. (1996). Biological invasions (Vol. 1). Springer.

Wolcott, G. N. (1923). The food of Porto Rican lizards. The Journal of the Department of Agriculture of Porto Rico, 7, 5-43.

Zou, Y., de Kraker, J., Bianchi, F. J. J. A., van Telgen, M. D., Xiao, H., \& van der Werf, W. (2017). Video monitoring of brown planthopper predation in rice shows flaws of sentinel methods. Scientific Reports, 7. https://doi.org/10.1038/srep42210

How to cite this article: Tresson P, Tixier P, Puech W, Carval D. The challenge of biological control of Cosmopolites sordidus Germar (Col. Curculionidae): A review. J Appl Entomol. 2021;00:1-11. https://doi.org/10.1111/jen.12868 